\title{
Arsenite Removal from Aqueous Solution using Mixed Mineral Systems Injected with Iron Sulfide under Sulfidic- Anoxic conditions 1: Reactivity and Removal Kinetics
}

\author{
D. E. Egirani ${ }^{1}$, J. E. Andrews ${ }^{2}$, A. R. Baker ${ }^{2}$ \\ ${ }^{1}$ Faculty of Science, Niger Delta University, Nigeria \\ ${ }^{2}$ School of Environmental Science, University of East Anglia, UK
}

\begin{abstract}
The reactivity and removal kinetics of arsenite treated with single and mixed mineral systems of kaolinite, montmorillonite and goethite injected with iron sulfide under sulfidic-anoxic conditions has been investigated. Using empirical models derived from Freundlich isotherm model, injection of sulfidic-anoxic solution of iron sulfide onto the mixed mineral systems enhanced proton coefficient of all single minerals. Differences in sorption kinetics between the single and mixed mineral phases may be attributed to different types of reactive sites on the single and mixed mineral systems Except for iron sulfide, kinetic studies demonstrated three phase reactions attributed to outer sphere complexation, inner sphere complexation and intra-particle diffusion. Injection of sulfidic-anoxic solution of iron sulfide could not change the three phase reaction trend.
\end{abstract}

Keywords: iron sulfide, kinetics, mixed minerals, reactivity, sulfidic-anoxic.

\section{Introduction}

Arsenic has caused human health problems world-wide. It is a naturally occurring toxic element having adverse effects on human health. Exposure of humans to elevated concentrations of arsenic in drinking water possess significant health risks, such as Blackfoot disease, skin, lung and bladder cancers, and disorders of the immune, nervous and reproductive systems[1-2]. Its sources are both natural and anthropogenic, occurring in soil, sediment, surface and groundwater. It is found naturally in the earth's crust, soil, sediment, and many kinds of rock and it may be transferred to water, groundwater, and air. Anthropogenic sources include wood preservatives, pesticides, insecticides and pigments. Most environmental arsenic problems are the result of mobilization under natural conditions, but man has had an important impact through mining activity, combustion of fossil fuels, the use of arsenical pesticides, herbicides and crop desiccants and the use of arsenic as an additive to livestock feed, particularly for poultry [3-5].

There is concern about removal of arsenic from water to the lower Maximum Contaminant Level (MCL) in drinking water because of its toxic nature [6]. Arsenic poisoning is a serious health concern worldwide and concentration above permissible limit in groundwater is one of the world's largest environmental calamities [7-8]. Groundwater enriched with arsenic species such as arsenite (As (III)) and organic arsenic has become one of the most serious problems in water environment $[1,9]$. It is particularly worse when the groundwater is utilized as drinking water [10-11]. The As(III) is more difficult to remove from water at neutral $\mathrm{pH}$ by means of adsorption and co-precipitation due to the lack of electrostatic attraction [12-13].

The human toxicity of arsenic ranges from skin lesions to cancer of the brain, liver, kidney, and stomach. Arsenic intake causes disturbance of nervous system functions and can lead to death [14-17]. Exposure of humans to high levels of arsenic in drinking water results in hyper-pigmentation, gangrene and gastrointestinal cancer [18]. Because of these effects, international agencies reduced the arsenic standard concentration in drinking water from 50 to $10 \mathrm{mg} / \mathrm{L} \mathrm{[19]}$.

The availability and migration of arsenic, a toxic metalloid, is controlled largely through sorption processes [20-21]. Under oxic conditions, arsenic adsorbs strongly to iron oxide surfaces [22-26] Surfacebound arsenic is released into solution under slightly reducing conditions through the reductive dissolution of the iron oxides [27-30]. Arsenate reduction to highly toxic trivalent arsenite, $\left(\mathrm{As}(\mathrm{OH})_{3}\right)$ may accompany its release into solution, potentially leading to widespread environmental contamination [31-34]. Arsenic concentrations typically decrease under anoxic conditions in ocean sediments [35-36], freshwater lakes [37-39], and rivers [40]. The uptake of arsenic in anoxic environments is strongly correlated with the formation of iron sulfide minerals including iron sulfide. The most important ores of arsenic are realgar $\left(\mathrm{As}_{4} \mathrm{~S}_{4}\right)$ and orpiment $\left(\mathrm{As}_{2} \mathrm{~S}_{3}\right)$. In the presence of sulfides, precipitation of realgar or orpiment can remove As(III) and have considerable control over arsenic concentrations. In addition, the quantity and speciation of arsenic depends on the local sorbent [41]. The most prevalent arsenic species depend on $\mathrm{pH}$ and the redox potential. As a general 
rule, arsenite, $\mathrm{As}(\mathrm{III})$, is more likely to be found in anaerobic ground water, whilst arsenate, $\mathrm{As}(\mathrm{V})$, is found in aerobic surface water [42].

The valence states of arsenic include: $\mathrm{As}(-\mathrm{III}), \mathrm{As}(0), \mathrm{As}(\mathrm{II}), \mathrm{As}(\mathrm{III})$, and $\mathrm{As}(\mathrm{V})$, It exists as sulfide minerals (e.g., $\mathrm{As}_{2} \mathrm{~S}_{3}$ ), elemental As, arsenite $\left(\mathrm{AsO}_{2}{ }^{-}\right)$, arsenate $\left(\mathrm{AsO}_{4}{ }^{3-}\right)$, or various organic forms that include methylated arsenates and trimethyl arsine. Both anionic forms (arsenite and arsenate) and deprotonated groups of arsenic are highly soluble and toxic and the chemical and microbiological reactions of arsenic are complex [43].

Two oxidation states, $\mathrm{As}(\mathrm{III})$ (arsenite) and $\mathrm{As}(\mathrm{V})$ (arsenate), predominate in surface and subsurface environments, depending on the redox potential. Between these two, As(III) is more mobile and more difficult to remove from groundwater under acidic and neutral $\mathrm{pH}$ conditions [1]. Also, arsenic can exist as thioarsenic aqueous species often found in sulfidic environments. In general, charged anionic species tend to be more strongly sorbed to mineral surfaces than neutral species. Also, compared to metal cations, which usually form highly insoluble oxide and hydroxide phases, arsenic exhibits higher solubility and mobility as dissolved species in aqueous solution under both oxidizing and reducing conditions [44-45]

Sorption processes largely control the migration and fate of arsenic in natural systems. Its solubility in natural systems is strongly influenced by adsorption at iron oxide surfaces.[46]. Natural sediments are heterogeneous and the overall sorption is the net result of the distinctly different sorption behavior on each constituent phase [47]. Arsenic mobilization in soils and acidic waters is controlled by sorption on newly formed precipitates (schwertmannite, jarosite and goethite), causing natural arsenic attenuation [48-51]. Therefore, successful treatment of water containing arsenic using mineral systems is dependent on a full understanding of the reactivity, fate and the transport of reaction partners to the reactive sites of arsenic- sorbents [52-56]. Dissolved arsenic is typically high for intermediate redox potential that results in dissolution of iron (hydr)oxides, in low oxic water when iron goethite are present [24, 46,57-58] and also usually low when iron sulfide minerals are present $[36,59]$.

The removal of arsenic from water is controlled by the Redox potential (Eh) and $\mathrm{pH}$, speciation, mobility, ionic size of the sorbing ions, sorbate composition, sorbent solubility, sorbent particle size, sorbent surface charge, surface area of the mineral sorbent, solution dilution and $\mathrm{H}+/ \mathrm{AsO}_{3}$ exchange stoichiometry [6062]. Arsenic ions occur in surface and ground waters in both organic and inorganic species, the inorganic forms being the predominant ones [63-64]. Under oxidizing conditions, $\mathrm{H}_{2} \mathrm{AsO}_{4}{ }^{-}$is dominant at low $\mathrm{pH}$, whilst at higher $\mathrm{pH}, \mathrm{HAsO}_{4}{ }^{2-}$ becomes dominant. Also, $\mathrm{H}_{3} \mathrm{AsO}_{4}{ }^{0}$ and $\mathrm{AsO}_{4}{ }^{3-}$ may be present in extremely acidic and alkaline conditions respectively). Under reducing conditions at $\mathrm{pH}$ less than 9.2, the uncharged arsenite species $\mathrm{H}_{3} \mathrm{AsO}_{3}$ will predominate [65, [9]. Therefore high arsenic waters are not expected where there is a high concentration of free sulfide Thioarsenite species will be more important at neutral and alkaline $\mathrm{pH}$ in the presence of very high sulfide concentrations [39].

Several methods have been established in the treatment of arsenic contaminated water. Some of these techniques include: synthetic iron sulfide [66], iron sulfide [67], troilite and iron sulfide [68-75]., sorption on ferrihydrite [76]., pristine iron sulfide and on surface-oxidized iron sulfide [77], vindhyan shales [8], iron monosulfides [78], natural siderite [79]., iron precipitates [51] , acid mine drainage [50], iron sediments [80], wood charcoal and fine sand filters [7]., iron oxides [27]., hydrous granular ferric oxide [81], activated alumina or bone char [18-82], engineered $\mathrm{H}_{2} \mathrm{~S}$-rich wetland [83]., natural zeolite and volcanic stone [84], natural iron ores [85], oxisol [86], red mud [87]], and ferruginous manganese ore [88], deep sea sediments [89], synthesized iron sulfide [90].

Iron sulfide, is known to exist in ambient sulfidic environments and reactions of iron sulfide with environmental contaminants have been studied extensively [91] and it has been shown that iron sulfide affects the speciation and mobility of arsenic [70, 92, 93]. Several studies have focused on the reactions of As(III) or $\mathrm{As}(\mathrm{V})$ with iron sulfide and other iron sulfides $[67,68,81,90,94-95]$. These studies have reported that $\mathrm{As}(\mathrm{V}) / \mathrm{As}(\mathrm{III})$ formed outer-sphere surface complexes with iron sulfide. In addition, substantial adsorption of As(III) on pyritic shales and the extent of sorption were correlated with iron sulfide content. Furthermore, adsorption on troilite ( $\mathrm{FeS}$ ) and iron sulfide $\left(\mathrm{FeS}_{2}\right)$ and reported $\mathrm{As}(\mathrm{III})$ sorbs to $\mathrm{FeS}$ and $\mathrm{FeS}_{2}$ through an innersphere mechanism distinct from those of surface hydroxyl exchange. Also, As(III) and As(V) were removed by synthetic iron sulfide due to formation of $\mathrm{As}_{2} \mathrm{~S}_{3}$ or $\mathrm{As}_{4} \mathrm{~S}_{4}$ surface phases. As(III) uptake by iron sulfide in a continuous-flow system and subsequent formation of arsenian iron sulfide has been reported [96] [ Singer and Stumm 1970]. Metal sorption on Iron sulfide under sulfidic conditions has been studied [97-99]. Iron sulfide coated surfaces on substrate had degradation effects on garlic under anaerobic condition [100].

Application of sulfides in water treatment is largely dependent on understanding of fundamental studies into metal sulphide precipitation and sorption mechanism on sulfide [101]. In addition, understanding of groundwater chemistry in a chemically reducing environment is focused on mechanisms of the reactivity and removal kinetics of sorbent-sorbate interactions.., there are some advantages to sulphide, including the lower solubility of metal sulphide precipitates, potential for selective metal removal and fast reaction rates, better 
settling properties and potential for re-use of sulphide precipitates by smelting [79, 102-104]. However, some of these new techniques are rather expensive for limited size water treatment systems in rural communities. Consequently, innovative cost-effective treatment processes are urgently needed. One of such emerging method is the use of mixed mineral systems of clays and hydroxide(s) injected with iron sulfide under sulfidic-anoxic conditions [80].

Nevertheless, information of arsenic sorption on mixed mineral systems is very limited [62] [Egirani et al 2013] and further testing using mixed mineral systems injected with iron sulfide under sulfidic-anoxic condition is needed. This study investigates the reactivity and removal kinetic component of arsenic sorption by mixed mineral systems clays and hydroxide(s) injected with iron sulfide under sulfidic-anoxic conditions [105] and to evaluate the effectiveness of these systems for arsenic removal. Mineral systems of clays, iron goethite and iron sulfide under sulfidic-anoxic conditions that could be applied for arsenic removal from contaminated water are readily available locally.

\subsection{Theoretical models and isotherms}

Sorption has been used as a technique for removal of arsenic. It is the process in which a chemical substance accumulates at the common boundary of two contiguous phases [106].If one of the contiguous phases is a solid and the other a fluid, the solid phase is termed the adsorbent, and the matter that sticks to the solid phase is called the adsorbate. The adsorbent is the iron sulfide and the adsorbate is the arsenic in this study. A related process occurs when a chemical is detached from a solid phase and this process is called desorption or negative adsorption. Typical adsorption experiments are conducted in a sequence of three steps [66]. First, the reaction between adsorbent and adsorbate is allowed to proceed for a prescribed period of time. Second, the adsorbent is separated from the liquid phase after a sufficient time passes for the removal reaction to be completed. Last, the amount of adsorbate remaining in the liquid phase is measured and the amount of adsorbate attached to the solid phase is calculated. Removal of the adsorbate by the adsorbent can be the beginning of the process. After that, chemical processes such as precipitation can occur, which can affect the total amount of material removed. Sorption is characterized by several isotherm models [107].

To addresses the suitability of mixed mineral suspensions of clays and goethite injected with iron sulfide for arsenite i.e. Arsenic (III) removal, a theory is designed to explain and predict the behavior of mineralarsenite interactions under sulfidic-anoxic conditions. Details of the empirical model derived from Freundlich isotherm model are provided [108-110].

Detailed system characterization and an empirical model involving the distribution coefficient (Kd) as used in this paper are provided in previous paper [110]. Kd was calculated from the Freundlich model as provided (1):

$$
S=K d C^{N}
$$

where $\mathrm{S}$ is the sorbed concentration $(\mu \mathrm{g} / \mathrm{kg}), \mathrm{Kd}$ is the distribution coefficient, $\mathrm{C}$ is the equilibrium concentration $(\mu \mathrm{g} / \mathrm{l})$, and $\mathrm{N}=1$ is a chemical-specific coefficient derived from the slope of the plot. The empirical model as provided [62] to address the mineral-arsenic interactions as provided (2):

$$
K d_{\text {total }}=\frac{K d_{1}+K d_{2}+K d_{n}}{n}
$$

where $\mathrm{Kd}_{\text {tota }} \mathrm{l}$ is the theoretical distribution coefficient for a 1:1 mixed suspension, $\mathrm{Kd}_{1}$ is the distribution coefficient for first single mineral suspension, and $\mathrm{Kd}_{2}$ is the distribution coefficient for second single mineral suspension, $\mathrm{Kdn}$ is the distribution coefficient for $\mathrm{n}$ number of mineral suspensions and $\mathrm{n}$ is the number of mineral suspensions. The simple empirical model used for the partitioning of a sorbed mercury contaminant between single mineral phases and mixed mineral phases is based on the assumptions that the following could account for differences between single and mixed mineral sorption:

a. Secondary mineral phase developed during sorbate-sorbent interaction.

b. Components of minerals in the mixed mineral suspension acted as chemisorbed species and not as individual networks.

c. differential mass of mixed and single mineral phases.

The difference between the actual sorption and the theoretical sorption was used to clarify the effects of mineral mixing injected with iron sulfide under sulfidic-anoxic condition on As(III) sorption. Mineral mixing is said to (a) enhance As(III) removal where the difference is positive; (b) depresses or attenuate As(III) removal where the difference is negative; and (c) have no effect on As(III) removal where no difference exist between As(III)sorbed and theoretical As(III) sorption [108]. 
The difference between the actual $\mathrm{Kd}$ and the theoretical $\left(\mathrm{Kd}_{\text {total }}\right)$ was used to clarify the effects of mineral mixing on arsenic removal under sulfidic-anoxic conditions. Mineral mixing is said to (a) enhances arsenic removal where the difference is positive; (b) attenuate arsenic removal where the difference is negative; and (c) have no effect on arsenic removal where no difference exist between the actual $\mathrm{Kd}$ and theoretical $\mathrm{Kd}$ as provided (3):

$$
\Delta K d=K d-K d \text { total }
$$

For the reactivity and removal kinetic studies, the empirical model for the mixed mineral systems was related to $\alpha$ and $\mathrm{Kf}$ as provided (4-5):

$$
\begin{aligned}
& \Delta \alpha=\alpha-\alpha \text { total } \\
& \Delta K_{f}=K_{f^{-K}} \text { f total }^{-K_{\text {tot }}}
\end{aligned}
$$

Where $\alpha, K_{f} \boldsymbol{\alpha}_{\text {total }}{ }^{\text {and }} K_{\text {f total }}$ are the proton coefficient, mass transfer rate,

theoretical proton coefficient and theoretical mass transfer coefficient, respectively. The main objective of this work is to determine the effects of mineral mixing on the reactivity and kinetics involved in arsenic removal from contaminated water under sulfidic-anoxic conditions. Mixed mineral suspensions of kaolinite, montmorillonite, goethite and iron sulfide used in this work were chosen to simulate natural minerals and sulfidic-anoxic conditions found in arsenic impacted groundwater aquifers [ 68].

The sorption kinetic model assumed that sorption rate was determined by sorption interaction between the sorbent reactive sites and the sorbate involving outer sphere complexation and inner sphere complexation [62, 111-112]. Otherwise, the intra-particle diffusion involving the diffusion of the adsorbate in the pore of the adsorbent as a third sorption reaction step was involved [108, 113]. This is due to the fact that surfaces of clays, hydroxides and sulfides have a high concentration of $\mathrm{OH}^{-}$and HS- groups readily deprotonated at high $\mathrm{pH}$, generating arsenic removal by precipitation [114-115] .

The mass balance of As(III) adsorbed per mass unit of the mixed mineral suspension (mg/g) was calculated by the following equation as provided (6) [79, 62, 116-120]:

$$
Q_{e}=\langle C i-C e\rangle \frac{V}{W}
$$

Where $\mathrm{Ci}$ and $\mathrm{Ce}$ are the initial and equilibrium metal concentrations in $\mathrm{mg} / \mathrm{l}, \mathrm{V}$ is volume of the metal solution in $\mathrm{mL}$ and $\mathrm{W}$ is the weight of adsorbent in $\mathrm{mg}$ respectively.

The main objective of this work is to determine the effects of mineral mixing on the reactivity and kinetics involved in arsenite removal from groundwater under sulfidic -anoxic condition. Mixed mineral suspensions of kaolinite, montmorillonite, and goethite used in this work were chosen to simulate natural minerals readily available.

\subsection{Preparation of sulfidic-anoxic iron sulfide suspension}

\section{Materials and methods}

Sulfidic-anoxic conditions are characterized by depletion of dissolved oxygen. These conditions will occur if the rate of oxidation is greater than the supply of dissolved oxygen [20]. In sulfidic-anoxic environment, hydrogen sulfide occurs as a product of sulfate and sulfide reduction [121]. In this study, $1 \%$ acidified iron sulfide sulfidic-anoxic suspension was prepared using deoxygenated deionized water. Purified nitrogen gas was bubbled through the iron sulfide suspension continuously for 24 hours. The content, securely sealed was stored in airtight containers in the anaerobic chamber in dark environment before use. The formation of hydrogen sulfide was prototypically characterized by a "rotten egg" odor [78].

\subsection{System characterization}

All solutions were prepared using de-aerated and deionized water. This water was prepared by bubbling purified nitrogen gas through deionized water for at least 24 hours. Deionized water was obtained from a Millipore Milli-Q system ( $\left.18 \mathrm{M}_{-}\right)$. Then the water was purged overnight in an anaerobic chamber containing a mixture of 5\% hydrogen and $95 \%$ nitrogen gases [90].

Clays and iron sulfide used in this study provided by the Richard Baker Harrison Company and Acros Organics Ltd and goethite provided by Iconofile Company Inc. were nitrogen flushed and stored in airtight 
containers in the anaerobic chamber before use to avoid oxidation. Arsenic (III) stock solution was purchased from Merck. The AAS standard solution of $1000 \mathrm{mg} / \mathrm{l}$ Arsenic(III) was prepared by transferring the contents of a Titrisol ampule with $\mathrm{As}_{2} \mathrm{O}_{3}$ in $\mathrm{H}_{2} \mathrm{O}$ (Merck, Germany) into a volumetric flask, which was filled up to the mark and stored at $20 \pm 20 \mathrm{C}$ according to the instructions by Merck. The working solutions of different concentrations were prepared by diluting the stock solution immediately before starting the batch studies [122]. For sorbent characterization, the (a) Coulter laser method was used to determine the particle sizes; (b) \% colloid was estimated from the particle size distribution curves; (c) equilibrium $\mathrm{pH}$ of the untreated mineral suspensions was determined using the Model 3340 Jenway ion meter; (d) the standard volumetric Brunauer, Emmett, and Teller (BET) method was used to determine the surface areas [123-124], (Table 1). (f) spectral analysis was performed using scanning electron microscopy, energy dispersive spectroscopy and x-ray diffraction to identify the mineral sorbent $[62,109125-126]$.

Table1: Characteristics of clays, goethite $[109,62]$ and Iron sulfide

\begin{tabular}{|l|l|l|l|l|}
\hline Mineral & $\begin{array}{l}\text { Particle size } \\
(\mu \mathrm{m})\end{array}$ & $\begin{array}{l}\%(<1 \mu \mathrm{m}) \\
\text { colloid }\end{array}$ & $\mathrm{pH} \pm \sigma$ & $\begin{array}{l}\text { Surface } \\
\left(\mathrm{m}^{2} / \mathrm{g}\right)\end{array}$ \\
\hline Kaolinite & $20.01 \pm 0.5$ & 3.00 & $6.05 \pm 0.05$ & $47.01 \pm 0.24$ \\
\hline Montmorillonite & $80.05 \pm 0.20$ & 0.53 & $2.01 \pm 0.09$ & $10.00 \pm 0.00$ \\
\hline Goethite & $40.10 \pm 0.15$ & 2.92 & $8.05 \pm 0.06$ & $71.05 \pm 0.17$ \\
\hline Kaolinite/montmorillonite & $80.05 \pm 50$ & 0.97 & $5.01 \pm 0.02$ & $88.05 \pm 0.55$ \\
\hline Montmorillonite/goethite & $15.25 \pm 0.24$ & 3.85 & $3.03 \pm 0.04$ & $147.10 \pm 0.50$ \\
\hline Kaolinite/goethite & $140.35 \pm 55$ & 0.73 & $3.05 \pm 0.01$ & $79.30 \pm 0.59$ \\
\hline Iron sulfide & $80.0 \pm 0.20$ & 4.729 & $4.02 \pm 0.03$ & $2.00 \pm 0.00$ \\
\hline
\end{tabular}

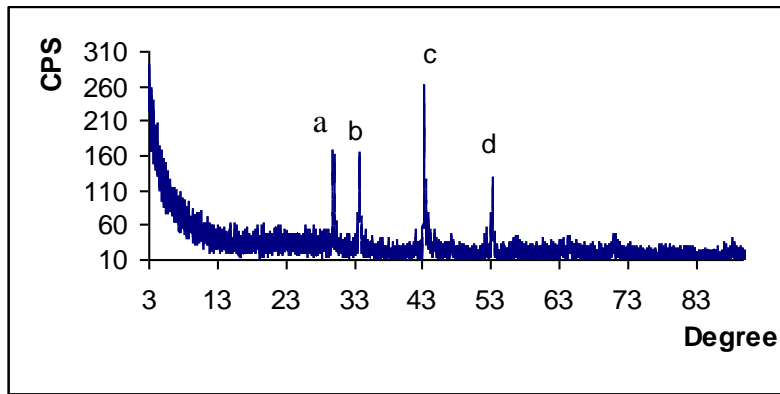

Figure 1 Untreated amorphous FeS showing peaks at a, b, c.

\subsection{Reactivity experiments}

For reactivity studies to determine the proton coefficient as provided (Eqs. (8-9), standard laboratory procedure was used [90, 127-128]. $1 \%$ sulfidic-anoxic suspension of iron sulfide was added to $1 \%$ single and 1:1 mixed mineral suspensions with no added electrolyte. The contents were reacted with solution containing $10 \mathrm{ppm}$ of arsenite regulated to the required $\mathrm{pH}$ at the start of experiments.

To validate the sorption mechanism involved in arsenite removal $1 \%$ sulfidic-anoxic suspension of iron sulfide was added to $1 \%$ single and 1:1 mixed mineral suspensions made up to $50 \mathrm{ml}$ were reacted with solution containing $10 \mathrm{ppm}$ of arsenite regulated to $\mathrm{pH}$ 4. Supernatant was filtered through a cellulose acetate filter (pore size $0.2 \mu \mathrm{m}$ ) and analyzed for arsenic(III), using a Hitachi Atomic Absorption Spectrophotometer (HG-AAS).

Spectroscopic studies have confirmed thiol $(\equiv \mathrm{S}-\mathrm{H})$ and hydroxyl $(\equiv \mathrm{Me}-\mathrm{OH})$ functional groups on surface of metal sulfides [93], [129-130]. These amphoteric reactive units are thought to undergo independent protonation and deprotonation reactions to produce reactive sites for sorption. Under acidic conditions, thiol groups are believed to play an important role in the reactivity of iron sulfide both in initial removal and subsequent surface reactions [62], [93]. The protonation of the iron sulfide surface makes it less negatively charged, at low $\mathrm{pH}$. At high $\mathrm{pH}$, the deprotonation of the surface makes it more negatively charged[113]. Sorption of arsenite on mineral surfaces requires proton exchange, the stoichiometry of this reaction is described $[109,62]$ and the proton consumption function is provided (7- 8):

$$
\square \mathrm{SOH}+3 \mathrm{AsO}_{3}{ }^{3-} \Rightarrow(\mathrm{SOH}) \square \square 3 \mathrm{AsO}_{3}{ }^{3-}+\square \mathrm{H}^{+}
$$

$\operatorname{LogKd}=\log (\mathbf{K p}\{\mathrm{SOH}\})+\square \mathbf{p H}$

8) 
where $\mathrm{SOH}$ is the mineral surface-binding site, $3 \mathrm{AsO}_{3}{ }^{3-}$ is the soluble arsenic species, $(\mathrm{SOH}) \alpha-3 \mathrm{AsO}_{3}{ }^{3-}$ is the surface bound arsenic, $\log \mathrm{Kp}$ is the apparent equilibrium binding constant, and $\alpha$ is the proton coefficient, representing the number of protons displaced when one mole of arsenite binds to the mineral surface [131]. Proton coefficient was calculated from the slope of $\operatorname{logKd}$ versus $\mathrm{pH}$ plot provided (Table 2, Fig. 4). Arsenic reactions within the aquatic environment [81] under sulfidic-anoxic conditions are provided (9-10):

$\mathrm{HAsO}_{2}+\mathrm{HS}^{-} \square$ AsS or AsS

$\mathrm{Fe}^{2+} \square$ FeS.HAs. $\mathrm{O}_{2}$

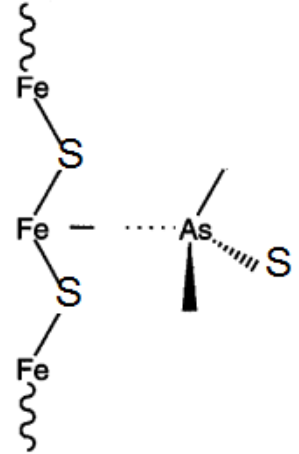

(a) Monodentate

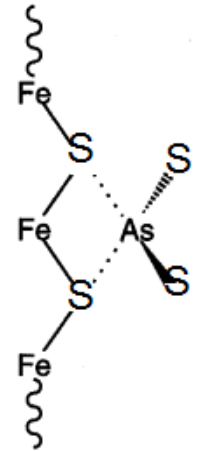

(b) Mononuclear bidentate

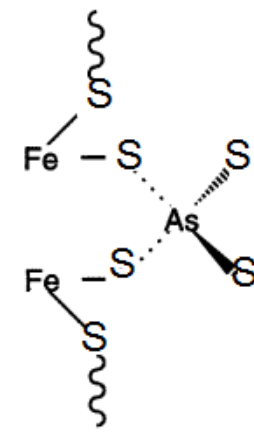

(c) Binuclear bidentate

Figure 2: proposed arsenic surface complexes in sulfidic-anoxic environment [modified from [132, 81]

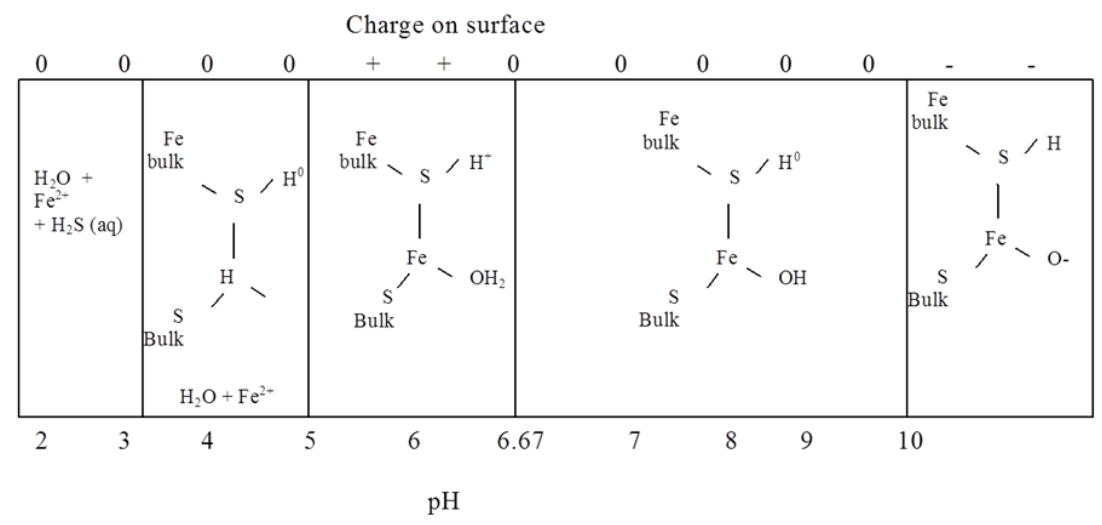

Figure 3: proposed surface species of iron sulfide at variable pH [134].

\subsection{Kinetic experiments}

For arsenic removal kinetics experiments, $1 \%$ sulfidic-anoxic suspension of iron sulfide was added to $1 \%$ single and 1:1 mixed mineral systems, reacted with solution containing $10 \mathrm{ppm}$ of arsenite regulated to $\mathrm{pH}$ 4. Amounts of arsenite remaining in solution after $2,4,6,8,12,18$, and $24 \mathrm{~h}$ were determined using Hitachi Atomic Absorption Spectrophotometer (HG-AAS). Twenty-four hours was sufficient for kinetic studies because sorption reactions occur in milliseconds or minutes $[62,135,46]$.

The transport of adsorbate from external layers to the mineral surface where sorption occurs is dependent on a mass transfer constant $\mathrm{Kf}$ obtained from the slopes of the curve derived from plotting $\mathrm{Ct} / \mathrm{C} 0 \mathrm{vs}$ time [66,136, 101, 137-139]., [109, 62] as provided (11):

$$
\left[\frac{\mathrm{d}\left(\mathrm{C}_{\mathrm{t}} / \mathrm{C}_{0}\right)}{\mathrm{dt}}\right]_{t=0} \cong-\mathrm{K}_{\mathrm{f}} \mathrm{Ss}
$$

where $\mathrm{C}_{0}$ is initial arsenic concentration $(\mathrm{mg} / \mathrm{l})$ at time $\mathrm{t}=0 ; \mathrm{C}_{\mathrm{t}}$ is arsenic concentrations $(\mathrm{mg} / \mathrm{l})$ at time t., $S$ s is the exposed external surface area of the sorbent, and $K_{f}$ is the mass transfer coefficient $[89,117]$. A higher inverse of $\mathrm{K}_{\mathrm{f}}$ suggests greater sorption The Freundlich isotherm was chosen to describe sorption of 
arsenite because this is suitable for heterogeneous surfaces over a wide range of solute concentrations [140142], [118].

At the end of equilibration, suspensions were shaken and centrifuged at $3000 \mathrm{rpm}$ for $15 \mathrm{~min}$ and passed through a $0.2-\mu \mathrm{m}$ filter to remove suspended solids. The amount of metal remaining in solution was then determined. In all experiments conducted, each treatment had three replicates and the differences in replicate runs were not statistically $(\chi 2)$ significant $(\mathrm{P} \leq 0.01)$.

\section{Results and discussion \\ 3.1. Mixed mineral systems and $\mathrm{H}+/ \mathrm{AsO}_{3}{ }^{3-}$ exchange stoichiometry}

Although the proton coefficient $(\alpha)$ ((Table 2, derived from Figs.4), may be linked to differences in the availability of strongly acidic sites. Previous study revealed proton coefficient for arsenite sorbed on single mineral systems greater than one except for goethite. Injection of sulfidic-anoxic solution of iron sulfide onto the mixed mineral systems enhanced proton coefficient of all single minerals. This indicates high level of protonation during the sorption process. Proton coefficient for arsenite-goethite interaction was higher than arsenite sorbed on kaolinite and iron sulfide. This could be attributed to amphoteric reactive units thought to undergo independent protonation and deprotonation reactions. In the presence of thiol $(\equiv \mathrm{S}-\mathrm{H})$ and hydroxyl $(\equiv \mathrm{Me}-\mathrm{OH})$ functional groups significant numbers of reactive sites in goethite and iron sulfide may increase the proton coefficient because of the enhanced exchange of protons for sorbing ions. Compared with previous study [62], injection of sulfidic -anoxic solution of iron sulfide did not change the trend of proton coefficient.

Table2: Proton coefficients $(\square)$ and regression coefficient $(\mathbf{R})$ of arsenite sorbed on mineral suspensions injected with sulfidic-anoxic iron sulfide

\begin{tabular}{|c|c|c|c|c|}
\hline $\begin{array}{l}\text { Mineral } \\
\text { suspensions }\end{array}$ & $\mathrm{R}$ & $\alpha$ & $\alpha_{\text {total }}$ & $\alpha_{\text {total }}^{\alpha-}$ \\
\hline Iron sulfide & 0.99 & 1.15 & $\otimes$ & $\otimes$ \\
\hline Kaolinite & 0.99 & 1.17 & $\otimes$ & $\otimes$ \\
\hline Goethite & 0.99 & 1.204 & $\otimes$ & $\otimes$ \\
\hline Montmorillonite & 0.99 & 1.243 & $\otimes$ & $\otimes$ \\
\hline Kaolinite/montmorillonite & 0.99 & 1.146 & 1.2065 & -0.0605 \\
\hline Goethite/kaolinite & 0.99 & 1.095 & 1.187 & -0.092 \\
\hline Goethite/montmorillonite & 0.99 & 1.294 & 1.2235 & 0.0705 \\
\hline
\end{tabular}

Note: $\otimes$ not applicable

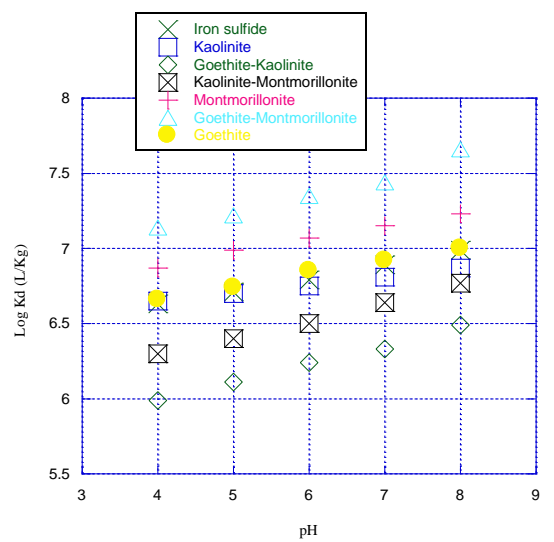

Figure 4: Plots of LogKd versus final pH for As (III) sorbed on iron sulfide, (b) goethite-kaolinite, (c) kaolinite-montmorillonite, (d) montmorillonite, (e) goethite-montmorillonite, (f) goethite, sulfidic-anoxic suspensions.

This is because except for montmorillonite/goethite mixed mineral system, $\alpha$ for arsenite sorbed on the remaining mixed suspensions were lower than $\alpha_{\text {total }}$, indicating increased protonation when montmorillonite was mixed with goethite under sulfidic-anoxic conditions. The higher the acidity of sites the more protons are exchanged for arsenite. Therefore, mineral mixing under sulfidic-anoxic condition could not enhance the acidity of reactive sites for all but one mixed minerals interacted with arsenite under sulfidic-anoxic condition. This may be due to the inability of sulfidic-anoxic solution of iron sulfide to counteract the competition of sorbing ions when these minerals are mixed. The $\mathrm{H}+/ \mathrm{AsO}_{3}{ }^{3-}$ exchange stoichiometry of $<2$ (Table 2) for arsenite sorbed on both the single and mixed mineral phases agrees with the findings of [62], for arsenic sorbed on clays and (hydr)oxides. This suggests that the presence of surface charges of thiol $(\equiv \mathrm{S}-\mathrm{H})$ and hydroxyl $(\equiv \mathrm{Me}-\mathrm{OH})$ 
functional groups through injection of sulfidic-anoxic iron sulfide solution does not significantly change protonation of reactive sites for the mixed mineral systems.

\subsection{Mixed mineral systems and sorption kinetics}

Previous study [62], reported a three phase reaction probably attributed to outer sphere, inner sphere complexation and intra-particle diffusion (Table 3, Fig 5). Injection of sulfidic-anoxic solution of iron sulfide could not change the three phase reaction trend. However, iron sulfide-interacted with arsenic exhibited a single phase reaction process. Previous study [62], revealed a mass transfer rate decrease in the order $\mathrm{K}_{\mathrm{fI}}<\mathrm{K}_{\mathrm{fII}}<\mathrm{K}_{\mathrm{fIII}}$ for all single mineral systems but goethite. Under sulfidic-anoxic condition mass transfer rate for the single minerals is in the order montmorillonite<goethite $<$ iron sulfide<kaolinite. For the mixed mineral systems, previous study [62], demonstrated a decrease in mass transfer rate for the mixed mineral systems in the order: $\mathrm{KfI}<\mathrm{KfII}<\mathrm{KfIII}$. Under sulfidic-anoxic condition, all KfI values are greater KfII but montmorillonite/goethite. Furthermore, all KfII values are greater than KfIII but kaolinite/goethite. Mineral mixing reduced mass transfer rate for arsenite treated with kaolinite/montmorillonite and montmorillonite/goethite. On the other hand, mineral mixing increased the mass transfer rate in all reaction phases for arsenite treated with kaolinite/goethite. Kaolinite/montmorillonite and montmorillonite goethite exhibited reduction in mass transfer rates due to mineral mixing but not necessarily due to injection of sulfidic-anoxic iron sulfide mineral solution. Differences in mass transfer rates of arsenite to the mineral reactive sites may be attributed (a) to different types of reactive sites on the single and mixed mineral systems (b) differences in surface area for the mineral systems and (c) differences in particle size distribution of these mineral systems as reported previously [62].

Table 3: Mass Transfer Rates for Arsenite Sorbed on Clay Minerals and Goethite sulfidic-anoxic suspensions

\begin{tabular}{|c|c|c|c|c|c|c|c|}
\hline $\begin{array}{l}\text { Parameters/ } \\
\text { Mineral }\end{array}$ & 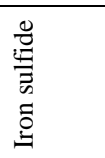 & 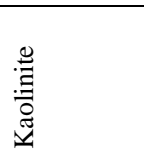 & 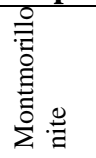 & 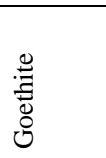 &  & 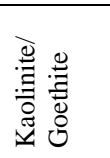 & 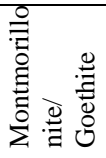 \\
\hline slopeI $\left(\mathrm{hr}^{-1}\right)$ & $-8.73 e-4$ & $-4.32 \mathrm{e}-2$ & -0.081 & $-2.42 \mathrm{e}-2$ & $-3.35 e-2$ & $-1.78 \mathrm{e}-2$ & $-2.42 \mathrm{e}-2$ \\
\hline slopeII $\left(\mathrm{hr}^{-1}\right)$ & $*$ & $-2.69 \mathrm{e}-2$ & -0.064 & $-4.06 \mathrm{e}-3$ & -0.02 & $-1.35 \mathrm{e}-2$ & $-1.46 \mathrm{e}-2$ \\
\hline Slope III $\left(\mathrm{hr}^{-1}\right)$ & $*$ & $-0.02 .70 \mathrm{e}-2$ & -0.048 & $-8.40 \mathrm{e}-3$ & -0.020 & $-1.43 e-2$ & $-1.47 \mathrm{e}-2$ \\
\hline $\begin{array}{l}\text { Exposed Surface Area } \\
\left(\mathrm{cm}^{-1}\right)\end{array}$ & 200 & 4700 & 1000 & 7100 & 8800 & 7900 & 14700 \\
\hline $\mathrm{K}_{\mathrm{f}} \mathrm{I}\left(\mathrm{cmhr}^{-1}\right)$ & $4.36 \mathrm{e}-6$ & $9.19 \mathrm{e}-6$ & $2.43 \mathrm{e}-4$ & $3.40 \mathrm{e}-6$ & $3.81 \mathrm{e}-6$ & $2.26 \mathrm{e}-6$ & $1.64 \mathrm{e}-6$ \\
\hline $\begin{array}{l}\text { Theoretical } \mathrm{K}_{\mathrm{f}} \mathrm{I}\left(\mathrm{cmhr}^{-}\right. \\
\left.{ }^{1}\right)\end{array}$ & $*$ & & & & $1.26 \mathrm{e}-4$ & $6.30 \mathrm{e}-6$ & $1.23 \mathrm{e}-6$ \\
\hline $\mathrm{K}_{\mathrm{f}} \mathrm{II}\left(\mathrm{cmhr}^{-1}\right)$ & $*$ & $5.72 \mathrm{e}-6$ & $9.72 \mathrm{e}-5$ & $5.72 \mathrm{e}-7$ & $2.27 \mathrm{e}-6$ & $1.71 \mathrm{e}-6$ & $9.92 \mathrm{e}-7$ \\
\hline $\begin{array}{l}\text { Theoretical } \mathrm{K}_{\mathrm{f}} \mathrm{II}\left(\mathrm{cmhr}^{-}\right. \\
\left.{ }^{1}\right)\end{array}$ & $*$ & & & & $5.15 e-5$ & $3.15 \mathrm{e}-6$ & $4.89 e-5$ \\
\hline $\mathrm{K}_{\mathrm{f}} \mathrm{III}\left(\mathrm{cmhr}^{-1}\right)$ & $*$ & $5.75 \mathrm{e}-6$ & $2.02 \mathrm{e}-5$ & $1.18 \mathrm{e}-6$ & $2.30 \mathrm{e}-6$ & $1.80 \mathrm{e}-6$ & $1.00 \mathrm{e}-6$ \\
\hline $\begin{array}{l}\text { Theoretical } \mathrm{K}_{\mathrm{f}} \mathrm{III} \\
\left(\mathrm{cmhr}^{-1}\right)\end{array}$ & $*$ & * & $*$ & * & $3.89 \mathrm{e}-5$ & $3.47 \mathrm{e}-6$ & $1.07 \mathrm{e}-5$ \\
\hline
\end{tabular}

Note: * Not applicable

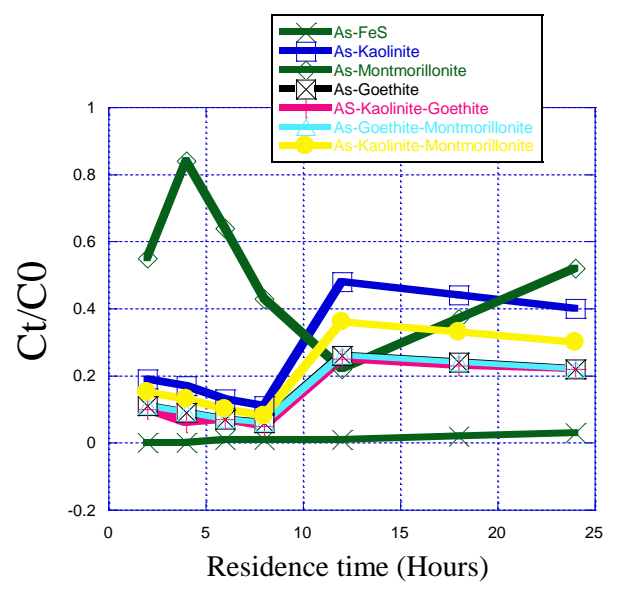

Figure 5: Effects of arsenite sorption on mass transfer rates: (a) iron sulfide, (b) kaolinite; (c) montmorillonite; (d) goethite; (e) kaolinite/goethite; (f) goethite/montmorillonite; (g) kaolinite/ montmorillonite sulfidic-anoxic suspensions. 


\subsection{Mixed mineral systems and arsenic removal}

Previous study [62], revealed a \% sorption still indicating a three phase reaction probably attributed to outer sphere, inner sphere complexation and intra-particle diffusion (Table 4, Fig 6). Except for arsenic sorbed on iron sulfide, mineral systems demonstrated increase in $\%$ sorption at the onset of reaction, indicating a reaction dip after 6 hours of contact or residence time. Reaction dip ended after 12 hours of residence or contact time, resulting in \% sorption increase for the rest of reaction time as previously reported [62]. This means that injection of sulfidic-anoxic mineral solution of iron sulfide could not significantly change the sorption characteristics of the single and mixed mineral systems. Iron sulfide as a single mineral system behaved differently from the clay minerals and hydroxides in arsenite sorption recording decrease in \% sorption over time.

Table 4: Arsenite Sorbed $(\mu \mathrm{g} / \mathrm{g})$ on Mineral Suspensions at pH 4, Zero Ionic Strength and 10ppm Initial Arsenic Concentration

\begin{tabular}{|l|l|}
\hline $\begin{array}{l}\text { Mineral } \\
\text { suspensions }\end{array}$ & Metal sorbed $(\mu \mathrm{g} / \mathrm{g})$ \\
\hline Iron sulfide & 8.83 \\
\hline Kaolinite & 8.85 \\
\hline Goethite & 8.86 \\
\hline Montmorillonite & 9.06 \\
\hline Kaolinite/montmorillonite & 8.45 \\
\hline Goethite/kaolinite & 8.00 \\
\hline Goethite/montmorillonite & 9.27 \\
\hline
\end{tabular}

This could be attributed to decrease in reactive sites and surface area high surface area as reaction proceeds over time (Table 1). Differences between actual and theoretical \% sorption was positive for all mixed minerals, indicating increase in \% sorption and no effect of sulfidic-anoxic mineral solution injection onto the mineral systems..

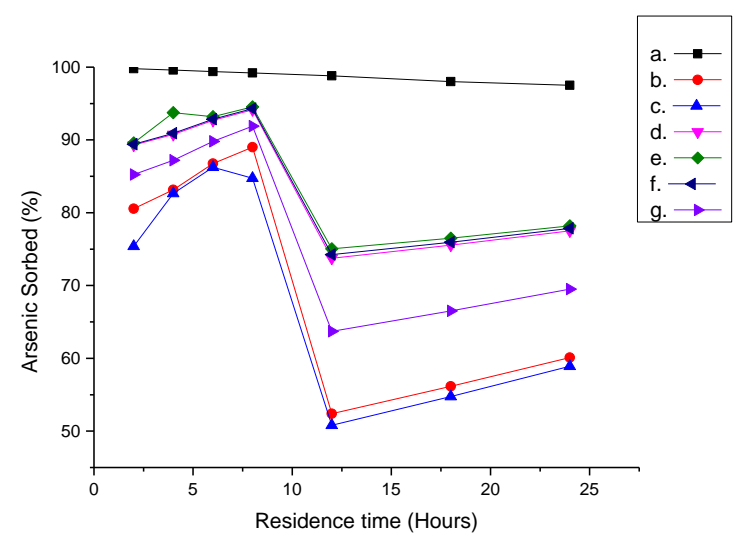

Figure 6: Plots of arsenic sorbed (\%) vs. contact time (hours): (a) Iron sulfide, (b) kaolinite; (c) montmorillonite; (d) goethite; (e) kaolinite/goethite; (f) goethite/montmorillonite; (g) kaolinite/ montmorillonite sulfidic-anoxic suspensions.

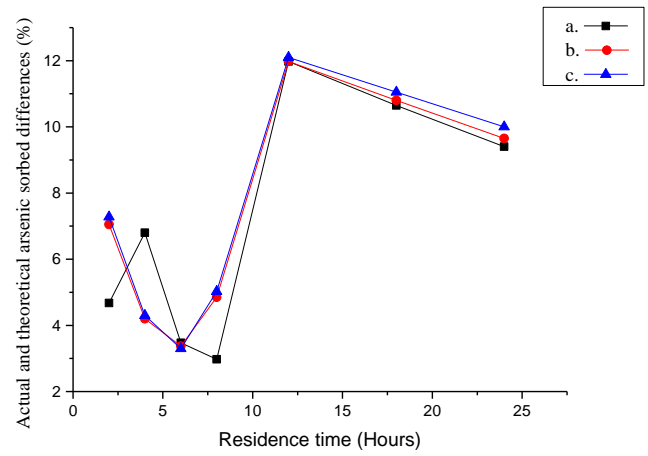


Figure 7: Plots of actual and theoretical arsenic sorbed differences(\%) vs. contact time (hours): (a) kaolinite/goethite; (b) goethite/montmorillonite;(c) kaolinite/montmorillonite sulfidic-anoxic suspensions.

\section{Conclusions}

The reactivity and removal kinetics of arsenite treated with single and mixed mineral systems of kaolinite, montmorillonite and goethite injected with iron sulfide under sulfidic- anoxic conditions has been investigated. Using empirical models derived from Freundlich isotherm model, injection of sulfidic-anoxic solution of iron sulfide onto the mixed mineral systems enhanced proton coefficient of all single minerals. This could be attributed to amphoteric reactive units thought to undergo independent protonation and deprotonation reactions. Proton coefficients in some cases are greater one, indicating high level of protonation during the sorption process. The $\mathrm{H}+/ \mathrm{AsO}_{3}{ }^{3-}$ exchange stoichiometry of $<2$ for arsenite sorbed on all mineral systems injected with sulfidic-anoxic mineral solution of iron sulfide suggests that maximum protonation was not achieved in all reaction phases.

Except for iron sulfide, kinetic studies demonstrated three phase reactions attributed to outer sphere complexation, inner sphere complexation and intra-particle diffusion. Injection of sulfidic-anoxic solution of iron sulfide could not change the three phase reaction trend. However, iron sulfide-interacted with arsenic exhibited a single phase reaction process. Under sulfidic-anoxic condition, all KfI values are greater KfII but montmorillonite/goethite. Furthermore, all KfII values are greater than KfIII but kaolinite/goethite. Mineral mixing reduced mass transfer rate for arsenite treated with kaolinite/montmorillonite and montmorillonite/goethite. Kaolinite/montmorillonite and montmorillonite goethite exhibited reduction in mass transfer rates due to mineral mixing but not necessarily due to injection of sulfidic-anoxic iron sulfide mineral solution. Differences in sorption kinetics between the single and mixed mineral phases may be attributed to different types of reactive sites on the single and mixed mineral systems

Except for arsenic sorbed on iron sulfide, mineral systems demonstrated increase in \% sorption at the onset of reaction, indicating a reaction dip after 6 hours of contact or residence time. Reaction dip ended after 12 hours of residence or contact time, resulting in \% sorption increase for the rest of reaction time as previously reported. This means that injection of sulfidic-anoxic mineral solution of iron sulfide could not significantly change the sorption characteristics of the single and mixed mineral systems.

\section{References}

[1]. P.L. Smedley, D.G. Kinniburgh, Review of Arsenic in natural water Appl. Geochem. 17 2002, )517-568

[2]. World Health Organization (WHO), Guidelines for drinking-water quality, Fourth edition. WHO, Geneva, Switzerland, 2011

[3]. C. A., Jones, H. W., Langner, K. Anderson, T. R. McDermott, and W. P. Inskeep, Rates of microbially mediated arsenate reduction and solubilization. Soil Sci. Soc. Am. J. 64, 2000, 600-608

[4]. N.J., Welham, K.A. Malatt, and S. Vukcevic, The effect of solution speciation on iron-sulphur-arsenic-chloride systems at 298K, Hydrometallurgy, 57: 2000, 209-223.

[5]. National Research Council, Arsenic: medical and biological effects of environmental pollutants. Technical report, National Academy of Sciences, Washington, DC. 1997,

[6]. United States Environment Protection Agency (USEPA), National Primary Drinking Water Regulations; Arsenic and Clarifications to Compliance and New Source Contaminants Monitoring, Washington, DC. 2001.

[7]. A. H. Khan1, S. B. Rasul2, A. K. M. Munir2, M. Habibuddowla3, M. Alauddin4, S. S. Newaz5 and A. Hussam, Appraisal of a Simple Arsenic Removal Method for Groundwater of Bangladeshj. Environ. Sci. Health, A35 (7), 2000, 1021-1041.

[8]. S. Paikaray, S. Banerjee, S. Mukherji, sorption of arsenic onto Vindhyan shales, Curr. Sci., 88 2005, p. $1580-1585$.

[9]. X.-P. Yan, R. Kerrich, M.J. Hendry, Distribution of arsenic (III), arsenic(V) and total inorganic arsenic in porewaters from a thick till and clay-rich aquitard sequence, Saskatchewan, Canada. Geochim. Cosmochim. Acta 64, 2000. 2637-2648.

[10]. National Research Council, Arsenic in Drinking Water: 2001 Update, National Academy Press, Washington, DC, 2001.

[11]. J.O. Nriagu, in: W.T. Frankenberger (Ed.), Environmental Chemistry of Arsenic, Dekker, New York, 2002 , p. 1.

[12]. E.O. Kartinen, J.M. Martin, An overview of arsenic removal processes, Desalination 103, 1995, 79-88

[13]. M. Bissen, F.H. Frimmel, Arsenic - a review. Part II: oxidation of arsenic and its removal in water treatment, Acta Hydrochim. Hydrobiol. 2003, 31 97-107.

[14]. M. Awual, S. A. REl-Safty, A, Jyo, Removal of trace arsenic(V) and phosphate from water by a highly selective ligand exchange adsorbent Spectrochimica Acta Part A 100, 2013, 161-165.

[15]. Q. Liu, H. Guo, Y. Li, H Xiang, , Acclimation of arsenic-resistant Fe(II)-oxidizing bacteria in aqueous environment International Biodeterioration \& Biodegradation 76, 2013, 86-91.

[16]. C.K.; Jain, I. Ali, Arsenic: Occurrence, toxicity and speciation techniques. Water Res., 34: 2000, 4304-4312.

[17]. H. S. Altundoðan, S.T Altundoðan, F. Men and, M., A., Bildik, rsenic removal from aqueous solutions by adsorption on red mud. Waste Manage., 2000, 20, 761-767.

[18]. T.J. Sorg, Treatment technologies to meet the interim primary drinking water regulations for inorganics. Part 2, J Am Water Works Assoc, 66, 7, 1978, 379-393.

[19]. World Health Organization (WHO), Guidelines For Drinking Water Quality, vol, 1.http://www.who.int/water_sanitation_health/dwq/GDW12rev1and2.pdf.http://www.who.int/water_sanitation_health/WHS_WWD 2010_guidelines_2010_6_en.pdf, 2006,,306-308.

[20]. W. R. Cullen and K. J. Reimer, Arsenic speciation in the environment. Chem. Rev. 89, 1989, $713-764$.

[21]. N. E. Korte and Q. Fernando, A review of arsenic(III) in groundwater. Crit. Rev. Environ. Control. 21, 1991, 1-39.

[22]. M. A., Anderson, J. F., Ferguson, and J., Gavis, Arsenate adsorption on amorphous aluminum hydroxide. J. Colloid Interface Sci. 54, 1976, 391-399.

[23]. G.A., Waychunas, B.A., Rea, C.C., Fuller, J.A., Davis, Surface-chemistry of ferrihydrite 1 EXAFS studies of the geometry of coprecipitated and adsorbed arsenate. Geochimica et Cosmochimica Acta 57, 1993. 2251-2269. 
[24]. B. A., Manning, S. E., Fendorf, and, S. Goldberg, "Surface structures and stability of arsenic(III) on goethite: Spectroscopic evidence for inner-sphere complexes." 88 Environ. Sci. Technol., 32(16), 1998. , 2383-2388

[25]. S., Fendorf, , M.J. Eick, , P., Grossl, D.L. Sparks, Arsenate and chromate retention mechanisms on goethite. 1. Surface structure. Environmental, Science and Technology 31, 1997. 315-320.

[26]. Hiemstra, T., Van Riemsdijk, W.H., Surface structural ion adsorption modeling of competitive binding of oxyanions by metal (hydr)oxides. J. Colloid Interface Sci. 210, 1999. 182-193.

[27]. F. Elbaz-Poulichet, C. Dupuy, A. Cruzado, Z. Velasquez, E. P. Achterberg, and C. B. Braungardt, Influence of Sorption Processes By Iron Oxides and Algae Fixation on Arsenic and Phosphate Cycle, In an Acidic Estuary (Tinto River, Spain), Wat. Res. Vol. 34, No. $12,2000,3222 \pm 3230$,

[28]. D. E Cummings., F Caccavo., S Fendorf., and R. F. Rosenzweig, Arsenic mobilization by the dissimilatory Fe(III)-reducing bacterium Shewanella alga BrY. Environ. Sci. Technol. 33, 1999, 723-729.

[29]. R. T. Nickson, J. M. McArthur, P. Ravenscroft, W. G. Burgess, and K. M Ahmed., Mechanism of arsenic release to groundwater, Bangladesh and West Bengal. Appl. Geochem. 15, 2000 , 403-413.

[30]. J., Zobrist, P. R Dowdle., J. A., Davis, and R. S., Oremland, Mobilization of arsenite by dissimilatory reduction of adsorbed arsenate. Environ. Sci. Technol. 34, 2000, 4747-4753.

[31]. R. Nickson, J. McArthur, W. Burgess, K. M., Ahmed, P. Ravenscroft, and M. , Rahman, Arsenic poisoning of Bangladesh groundwater. Nature 395, 1998, 338

[32]. S. K. Acharyya, P. Chakraborty, S. R. Lahiri, B. C. Aymahashay, S. Guha, and A., Bhowmik, Arsenic poisoning in the Ganges Delta. Nature 401, 1999, 545.

[33]. H. W. Langner,; W. P. Inskeep, Environmental Science and Technology. 2000, 34, 3131-3136.

[34]. B'Hymer, C. and Caruso, J. A., Arsenic and its speciation analysis using high-performance liquid chromatography and inductivelycoupled plasma mass spectrometry. J. Chromatogr. A, 2004, 1045,1-13.

[35]. G.A. Cutter, Dissolved arsenic and antimony in the Black Sea.Deep-Sea Res. 38, (1991), 825-843.

[36]. Sullivan K. A. and Aller R. C., Diagenetic cycling of arsenic in Amazon shelf sediments. Geochim. Cosmochim. Acta 60, 1996, 1465-1477.

[37]. J. Aggett and G. A, O'Brian, Detailed model for the mobility of arsenic in lacustrine sediments based on measurements in Lake Ohakuri. Environ. Sci. Technol. 19, 1985 , 231-238.

[38]. Balistrieri L. S., Murray J. W., and Paul B., The geochemical cycling of trace elements in a biogenic meromictic lake. Geochim. Cosmochim. Acta 58, 1994, 3993-4008.

[39]. J.N. Moore, W.H. Ficklin, C. Johns, Environ. Sci. Technol. 22, 1988, 432.

[40]. K. H., W. B. Lyons, E. Y. Graham, and K. A., Welch, Oxyanion concentrations in eastern Sierra Nevada rivers: 3. B Johannesson oron, molybdenum, vanadium, and tungsten. Aquat. Geochem. 6, 2000, 19-46.

[41]. K.J. Nath, and A.,, Majumder, Arsenic in groundwater: methodology for removal, In B. A. Hoque, S. A. Ahmed, G. Morshed, A.A.K.M. Shafique, \& B. N. Kabir (Eds.), Measurement and Mitigation Strategies for Arsenic in Drinking Water at the Field Level. Outcome of a Workshop 1998. 21-30).

[42]. J.F. Ferguson, and J., Gavis, A review of the arsenic cycle in natural waters, Water Res, 6: 1971, $1259-1274$.

[43]. V. M., Boddu, K., Abburib, J. L., Talbottc, E. D., Smitha, \& R. Haasch, Removal of As(III) and As(V) from aqueous medium using chitosan-coated biosorbent.Water Research, 42, 2008, 633-642.

[44]. S.A., Wood, C.D Tait, and D.R., Janecky, A Raman spectroscopic study of arsenite and thioarsenite species in aqueous solution at 25 degrees C. Geochemical Transactions 3, 2002, 31-39.

[45]. H.L. Lien, and R.T., Wilkin, High-level arsenite removal from groundwater by zero-valent iron. Chemosphere 59(3), 2005, 377386.

[46]. K. P., Raven, A. Jain, and R. H., Loeppert, Arsenite and arsenate adsorption on ferrihydrite: Kinetics, equilibrium and adsorption envelops. Environ. Sci. Technol., 1998, 32, 344-349.

[47]. C. D Church, R.T Wilkin, C. N Alpers, R. O Rye and R B. McCleskey, Microbial sulfate reduction and metal attenuation in pH 4 acid mine water, Geochemical Transactions, 8: 200, 10 .

[48]. A. C. Bergera, C. M. Bethkea, J. L. Krumhansl, A process model of natural attenuation in drainage from a historic mining district Applied Geochemistry 15, 2000, 655-666.

[49]. O. Sracek, J. Filip, M. Mihaljevi, B. K`ríbek, V. Majer, F. Veselovský, Attenuation of dissolved metals in neutral mine drainage in the Zambian Copperbelt, Environ Monit Assess 172, 2011, 287-299.

[50]. A. G. Gaulta,, D. R. Cookeb, A.T. Townsendc, J. M. Charnocka, D.A. Polyaa, Mechanisms of arsenic attenuation in acid mine drainage from Mount Bischoff, western Tasmania, Science of the Total Environment, 345, 2005, $219-228$.

[51]. M.P. Asta, C. Ayora, G. Román-Ross, J. Cama, P. Acero, A. G. Gault, J.M. Charnock, F.Bardelli, and Natural attenuation of arsenic in the Tinto Santa Rosa acid stream (Iberian Pyritic Belt, SW Spain): The role of iron precipitates Chemical Geology 271, 2010, 112.

[52]. C.H., Gammons, A.K., Frandzen, Fate and transport of metals in H2S-rich waters at a treatment wetland. Geochemical Transactions 2, 2001, 1-15.

[53]. M. Dalmacija, M. Prica, , B Dalmacija, S. Roncevic , M Klasnja, Quantifying the environmental impact of As and Cr in stabilized/solidified materials, Science of the Total Environment 412-413, 2011, 366-374.

[54]. C.K.; Jain, Ali, I. Arsenic: Occurrence, toxicity and speciation techniques. Water Res., 34:2000, 430424.

[55]. V.H. Hatje, D.M. Hill, G. McOrist, G.F. Birch, R. Szymczak, Kinetics of trace element uptake and release by particles in estuarine waters: effects of pH, salinity, and particle loading, J. Environ. Int. 29, 2003, 613-618.

[56]. A. Pohlmeier, H., Lustfeld, Reaction rates of heavy metal ions at goethite: Relaxation experiments and modeling J. Colloid Interface Sci. 269, 2004, 131- 142.

[57]. S., Dixit, J.G., Hering, Comparison of arsenic (V) and arsenic (III) sorption onto iron oxide minerals: Implications for arsenic mobility. Environmental Science and Technology 37, 2003, 4182-4189.

[58]. 58. J. Gimenez, J. de Pablo, M. Martinez, M. Rovira, C. Valderrama, Reactive transport of arsenic(III) and arsenic(V) on natural hematite: Experimental and modeling J. Colloid Interface Sci., 348 , 2010, 293-297.

[59]. H.A, Lowers, G.N. Breit, A.L. Foster, J.Y. Whitney, J. Yount M.N. Uddin, A.A Muneem., Arsenic incorporation into authigenic iron sulfide, Bengal Basin sediment, Bangladesh, 2007, 2699-2717.

[60]. Kumaresan M., Riyazuddin, P., Overview of speciation chemistry of arsenic, Curr. Sci. 80, 2001, 837-846.

[61]. M. Waeles J., Vandenhecke, P. Salaun, J. Cabon, R.D. Riso, External sources vs internal processes: What control inorganic As speciation and concentrations in the Penze estuary, Journal of Marine Systems 109-110, 2013, 261-272. 
[62]. D.E. Egirani,, A.R Baker, and, J.E, Andrews, Arsenite Removal from Aqueous Solution by Mixed Mineral Systems I. Reactivity and Removal Kinetics, International Journal of Recent Scientific Research 4(4), 2013, 357 - 363.

[63]. S. Srivastava, M. Shrivastava, P. Suprasanna, S.F. D’Souza, Phytofiltration of arsenic from simulated contaminated water using Hydrilla verticillata in field conditions, Ecological Engineering, 37, 2011,1937- 1941

[64]. M. A., Fazal, \&, T., Kawaci, Extent and severity of ground water arsenic contamination in Bangladesh. Water International, 26(3), 2001, 370-379.

[65]. D. G. Brookins, Eh-pH Diagrams for Geochemistry. Springer-Verlag Berlin, New York. 1988.

[66]. J. Han, K.. Song, B B. atchelor A. Abdel-Wahab, Removal of arsenite and arsenate by synthetic pyrite $\left.(\text { FeS })_{2}\right)$ Synthesis, effect of contact time, and sorption/desorption envelopes Journal of Colloid and Interface Science 392, 2013, 311-318.

[67]. M., Wolthers, I.B. Butler,, D., Rickard, P.R.D. Mason, Arsenic incorporation into iron sulfide at ambient environmental conditions: a continuous-flow experiment. In: O'Day, P.A., Vla ssopoulos, D., Ming, X., Benning, L.G. (Eds.), Advances in Arsenic Research: Integration of Experimental and Observational Studies and Implications for Mitigation. American Chemical Society Symposium Series, 915, 2005. 60-76.

[68]. B. C. Bostick, and S., Fendorf, Arsenite sorption on troilite (FeS) and iron sulfide (FeS2). Geochim. Cosmochim. Acta, 67, 2003, 909-921.

[69]. B. C., Bostick S., Fendorf B. T., Bowie and P. R. Griffiths, Influence of cadmium sorption on FeS 2 oxidation. Environ. Sci. Technol. 34, 2000, 1494-1499.

[70]. M.A., Huerta-Diaz, , J.W., Morse Pyritization of trace metals in anoxic marine sediments. Geochim. Cosmochim. Acta 56, 1992. 2681-2702.

[71]. D. C. Cooper and J. W. Morse, The chemistry of Offats Bayou; Texas: A seasonally highly sulfide basin. Estuaries 19, 1996, 595611.

[72]. M., Soma A., Tanaka H., Seyama and K., Satake Characterization of arsenic in lake sediments by X-ray photoelectron spectroscopy. Geochim. Cosmochim. Acta 58, 1994, 2743-2745.

[73]. 73. M. J., LaForce C. M., Hansel and S. Fendorf, Arsenic speciation, seasonal transformations, and co-distribution with iron in a mine 920 B. C. Bostick and S. Fendorf waste-influenced palustrine emergent wetland. Environ. Sci. Technol. 34, 2000 , 3937-3943.

[74]. M. Sadiq, Arsenic chemistry in marine environments: A comparison between theoretical and field observations. Mar. Chem. 31, 1990, 285-297.

[75]. Sadiq M. Arsenic chemistry in soils: An overview of thermodynamic predictions and field observations. Water Air Soil Poll. 93, $1997,117-136$.

[76]. K. R a v e n, A. .J a i n, a n d R. . L o e p p e r t, Arsenite and Arsenate Adsorption on Ferrihydrite: Kinetics, Equilibrium, and Adsorption Envelopes Environ. Sci. Technol., 32, 1998, 344-349.

[77]. F. Suna, B. A. Dempseya, , Kwadwo A. Osseo-Asareb, , As(V) and As(III) reactions on pristine iron sulfide and on surfaceoxidized iron sulfide Journal of Colloid and Interface Science Volume 388, Issue 1, 2012, 170-175

[78]. R.T. Wilkin, H.L. Barnes, Geochim. Cosmochim. Acta 60, 1996, 4167.

[79]. X., Guo, Y., Du, F., Park, Hung-Suck, , Y., Xie, Mechanism of removal of arsenic by bead cellulose loaded with iron oxyhydroxide (b-FeOOH): EXAFS study. J. Colloid Interf. Sci. 314 (2), 2007, 427-433.

[80]. R. A. Root, S. Dixit, K. M. Campbell, A. D. Jew, J. G. Hering, Peggy A. O’Day Arsenic sequestration by sorption processes in high-iron sediments, Geochimica et Cosmochimica Acta 71, 2007, 5782-5803.

[81]. M. Streat *, K. Hellgardt *, N.L.R. Newton, Hydrous ferric oxide as an adsorbent in water treatment, Part 2. Adsorption studies p r o c e s s sa f e t y and e $\mathrm{n} v$ i ronmental p rot e c ti on $86,2008,11-20$.

[82]. A.; Ghosh, M.; Mukiibi, W. Ela, Environmental Science and Technology. 38, 2004, 4677-4682.

[83]. C. H. Gammonsa and A. K. Frandsenb, Fate and transport of metals in $\mathrm{H}_{2} \mathrm{~S}$-rich waters at a treatment Wetland Geochem. Trans., 1 , 2001,

[84]. M.P. Elizalde-González, J. Mattusch, W.D. Einicke, R. Wennrich, Chem. Eng. J. 81, 2001, 187.

[85]. W. Zhang, P. Singh, E. Paling, S. Delides, Miner. Eng. 17, 2004, 517.

[86]. A.C.Q. Ladeira, V.S.T. Ciminelli, Water Res. 38, 2004, 2087.

[87]. H. Genç-Fuhrman, J.C. Tjell, D. McConchie, O. Schuiling, J. Colloid Interface Sci. 264, (2003, 327.

[88]. S. Chakravarty, V. Dureja, G. Bhattacharyya, S. Maity, S. Bhattacharjee, Water Res. 36, $2002,625$.

[89]. M. Ujević Bošnjaka, ., C. Casiotb,., Ž. Duićc,.., S. Fazinićd, J. Halamiće, L. Siposf, V. Santog,Ž. Dadića, Sediment characterization and its implications for arsenic mobilization in deep aquifers of eastern Croatia, Journal of Geochemical Exploration, 126-127, 2013, 55-66.

[90]. E.J. Kim, B. Batchelor, Environ. Sci. Technol. 43 (2009) 2899..

[91]. R. Murphy, D.R. Strongin, surface reactivity of iron sulfide and related sulfides, Surf. Sci. Rep., 64, 2009, 1-45.

[92]. A. Naveau, F. Monteil-Rivera, E. Guillon, J. Dumonceau, XPS and XAS studies of copper sorbed onto a synthetic iron sulfide surface, J. Colloid Interface Sci., 303, 2006, 25-31.

[93]. P. Bonnissel-Gissinger, M. Alnot, J.J. Ehrhardt, P. Behra, surface oxidation of iron sulfide as a function of pH, Environ. Sci. Technol., 32, 1998, 2839-2845.

[94]. M.L. Farquhar, J.M. Charnock, F.R. Livens, D.J. Vaughan, Environ. Sci. Technol. 36 (2002) 1757.

[95]. K.M, Rosso., DJ, Vaughan., reactivity of sulfide surfaces, Rev. Miner. Geochem. 61, 2006, 557-607,

[96]. P.C. Singer, W. Stumm Science, 167 (1970), p. 1170

[97]. SR. Emerson \& SS, Huested, Mar. Chem, 34, 1991, 177-196.

[98]. C.; Amrhein, P. A.; Mosher, A. D. Brown, Soil Science. 155, 1993, 249-255.

[99]. J, Crusius S, Calvert T Pedersen \& D, Sage, Earth Planet. Sci. Let, 145, (1996 65-78.

[100]. U. Szewzyk and B. Schink Attachment to amorphous iron sulfide increases the activity of strictly anaerobic, gallic acid-degrading bacteria, Microbiology Letters, 78, 1991, 115-120.

[101]. U. von Gunten, Kinetics and mechanistic aspects of As(III) oxidation by aqueous chlorine, chloroamines, and ozone: Relevance to drinking water treatment. Environ. Sci. Technol. 40, 2006, 3285-3292.

[102]. N. Belzile, The fate of arsenic in sediments of the Laurentian Trough. Geochim. Cosmochim. Acta 52, 1988, 2293-2302

[103]. 103. D. C. Cooper and J. W. Morse, Extractability of metal sulfide minerals in acidic solutions: Applications to environmental studies of trace metal contamination with anoxic sediments. Environ. Sci. Technol. 32, 1998, 1076-1078.

[104]. J. Holmes, Fate of incorporated metals during iron sulfide oxidation in seawater. Appl. Geochem. 14, 1999, $277-281$.

[105]. T. Ahmad, M.A. Kahlown, A., Tahir, H., Rashid, Arsenic an emerging issues: experiences from Pakistan. In: 30th WEDC International Conference, Lao PDR, Vientiane. 2004. 
[106]. M., Badruzzaman, P., Westerhoff, \& D. R. U. Knappe, Intraparticle diffusion and adsorption of arsenate onto granular ferric hydroxide. Water Research, 38, 2004, 4002-4012.

[107]. P.H, Brunauer, S. Emmett,. E. Teller, Adsorption of gases in multimolecular layers, J. Am. Chem. Soc. 60, 1938, 309-319.

[108]. D.E., Egirani, A.R Baker, and J.E, Andrews, Arsenite Removal from Aqueous Solution by Mixed Mineral Systems II. The Role of Solution Composition and Ageing, International Journal of Recent Scientific Research Vol. 4, Issue, 4, 2013,439 - 443.

[109]. D.E., Egirani, A.R Baker, and J.E, Andrews, Copper and zinc removal from aqueous solution by mixed mineral systems I: Reactivity and removal kinetics Journal of Colloid and Interface Science 291: 2005a , 319-325.

[110]. D.E., Egirani, A.R Baker, and J.E, Andrews, Copper and zinc removal from aqueous solution by mixed mineral systems II: The role of solution composition and aging. Journal of Colloid and Interface Science 291:2005b, 326-333.

[111]. E. Tombacz, G. Filipcseis, M. Szekeres, Z Gingl,. Particle aggregation in complex aquatic systems J. Colloids Surf. 15, 1999, 233-244.

[112]. D. M., Sherman \& S. R. Randall, Surface complexation of arsenic (V) to iron (III) hydroxides: Structural mechanism from ab initio molecular geometries and EXAFS spectroscopy. Geochimica et Cosmochimica Acta, 67, 2003, 4223-4230.

[113]. V., Ernstsen, G., Ona-Nguema, C. Upadhyay, and C. Ruby, Fougerite and FeII-III hydroxycarbonate green rust; ordering deprotonation and/or cation substitution; structure of hydrotalcite-like compounds and mythic ferrosic hydroxide $\mathrm{Fe}(\mathrm{OH})((2+\mathrm{x}))$. Solid State Sci. 7(5), 2005, 545-572.

[114]. R. T. Wilkin and H. L. Barnes, Formation processes of framboidal iron sulfide, Geochim. Cosmochim. Acta, 1997, 61, 323.

[115]. M.B. McBride, Organic anions adsorption on aluminum hydroxides: spin probe studies,. Clay and clay minerals, 30(4), 1982, 438444.

[116]. D. E Giles, M. Mohapatra, T. B Issa, S. Anand, P. Singh, Iron and aluminium based adsorption strategies for removing arsenic from water Journal of Colloid and Interface Science 392, 2013, 311-318.

[117]. Y.S. Al-Degs, M.F. Tutunji, H.M Baker, Isothermal and kinetic adsorption behaviour of Pb" ions on natural silicate minerals. J. Clay Miner. 38, 2003, 501-509.

[118]. J.E. McLean, B.E Bledsoe, Behaviour of Metals in Soils, U.S. Environmental Protection Agency, Washington, DC. 1992,

[119]. T., Altun, \& E. Pehlivan, Removal of Cr(VI) from aqueous solutions by modified walnut shells. Food Chemistry, 132, 2012, 693700 .

[120]. J.B.Brower, R.L Ryan and M. Pazirandeh. Comparison of ion exchange resins and biosorbings for the removal of heavy metals from plating factory wastewater. Environmental Science \& Technology, 31, 1997, 2910-2914.

[121]. A., Velasco, M., Ramírez, , T., Volke-Sepúlveda, A., González-Sánchez, , S., Revah, Evaluation of feed COD/sulfate ratio as a control criterion for the biological hydrogen sulfide production and lead precipitation. Journal of Hazardous Materials 151 (2-3), 2008, 407-413.

[122]. V.K., Gupta, V.K. Saini, and, N., Jain, . Adsorption of As(III) from aqueous solutions by iron oxide-coated sand. Journal of Colloid and Interface Science 288(1), 2005, 55-60.

[123]. A. Anso'n, J. Jagiello, J. B. Parra, M. L. Sanjua'n, A.M. Benito, W.K. Maser, and M. T. Martı'nez. Porosity, Surface Area, Surface Energy, and Hydrogen Adsorption in Nanostructured Carbons, J. Phys. Chem. B 108, 2004, 15820-15826.

[124]. J., Hlavay, \& K. Polyak, Determination of surface properties of ironhydroxide-coated alumina adsorbent prepared for removal of arsenic from drinking water. Journal of Colloid and Interface Science, 284, 2005, 71-77.

[125]. M. Zhang, B. Gao S. Varnoosfaderani A. Hebard, Y., Yao, M. Inyang, Preparation and characterization of a novel magnetic biochar for arsenic removal, Journal of environmental Sciences,, 23(12), 2011, 1947-1954.

[126]. G. C. Silva, F. S. Almeida, M. S Dantas, . A Ferreira,. V. S.T MCiminelli, Raman and IR spectroscopic investigation of As adsorbed on Mn3O4 magnetic Composites, Separation Science and Technology, 46: 2011, 2531-2538.

[127]. D.L, Sparks, Environmental Soil Chemistry (Ed.). University Press London, 2003, 150-162.

[128]. N Cavallaro, and M. B. McBride Copper and cadmium adsorption characteristics of selected acid and calcareous soils, Soil Sci. Soc. Am. J. 42: 978, 550-556.

[129]. A.R., Lennie, D.J., Vaughan, Spectroscopic studies of iron sulfide formation and phase relations at low temperatures. Min. Spectr., special publ, vol. 5, , 1996, 117-131.

[130]. H. W. Nesbitt, and I. J. Muir, X-ray photoelectron spectroscopic study of a pristine iron sulfide surface reacted with water vapour and air. Geochim. Cosmochim. Acta 58, 1994, 4669-4679.

[131]. Z.S. Kooner, Comparative study of adsorption behavior of copper, lead, and zinc onto goethite in aqueous systems. Environ. Geol. 21, 1993, 242-250.

[132]. P. H., Davis, , G. R., Dulude, R. M., Griffin, W. R. Matson, and E. W., Zink, Anal. Chem. 50, 137-143 (1978).

[133]. A, S. Breitbach, Nanoparticles in the Environment: A Study of Surface Reactivity of Pyrite and Arsenopyrite Materials - NNIN REU, Research Accomplishments, 2006, 53-55.

[134]. T.J., Gallegos, Y.S. Han, and K.F., Hayes, Model predictions of realgar precipitation by reaction of As(III) with synthetic iron sulfide under anoxic conditions. Environmental Science \& Technology 42(24), 2008. 9338-9343.

[135]. J.D Morton, J.D. Semaru, K.F. Hayes, An X-ray absorption spectroscopy study of the structure and reversibility of copper adsorbed to montmorillonite clay, Geochim. Cosmochim. Acta 65, 2001, 2709-2722.

[136]. H. Hong, 1 J. Yang, B. Kim. J. Yang, Arsenic Removal Behavior by Fe-Al Binary Oxide: Thermodynamic and Kinetic Study Journal of Environmental Management 92, 2011, 3011-3022.

[137]. K., Banerjee, G.L. Amy,, M. Prevost,, , S., Nour, M., Jekel, , P.M., Gallagher, C.D. Blumenschein,, Kinetic and thermodynamic aspects of adsorption of arsenic onto granular ferric hydroxide (GFH). Water Res. 42 (13), 2008, 3371-3378.

[138]. T. S., Singh, \& K. K. Olarinoye, Equilibrium, kinetics and thermodynamic studies for adsorption of As(III) on activated alumina. Separation and Purification Technology, 36, 2004, 139-147.

[139]. I.A., Oke, N.O., Adewusi, S.R.A., 2008, Adsorption kinetics for arsenic removal from aqueous solutions by untreated powdered eggshell. Adsorption 14, 73-83.

[140]. A.V. Vitela-Rodriguez, J. R. Rangel-Mendez, Arsenic removal by modified activated carbons with iron hydro(oxide) nanoparticles Journal of Environmental Management 114, 2013, 225-231.

[141]. C.W. Oo, M.J. Kassim, A. Pizzi, Characterization and performance of Rhizophora apiculata mangrove polyflavonoid tannins in the adsorption of copper (II) and lead (II), Ind. Crop. Prod. 30, 2009, 152-161.

[142]. D. A. Dunnette, D. P. Chynoweth and K. H. Mancy, The Source of Hydrogen Sulfide in Anoxic Sediment, Water Re I9(7) 1985, 875-884. 